\title{
The Correlation of Pemogan Community Knowledge about Usada Taru Pramana with the Behaviour of Utilization and Conservation of Herbal Medicine
}

\author{
Ni Putu Udayana Antari*, I Putu Tangkas Suwantara, Erna \\ Akademi Farmasi Saraswati Denpasar. Jalan Kamboja No. 11A, Denpasar, Indonesia.
}

\begin{abstract}
Usada Taru Pramana is a record of hundreds medicinal plants. Researcher is interested to know the knowledge level of Pemogan Villager about Usada Taru Pramana and its influence on the utilization behavior and conservation of herbal medicine. Data were collected using a valid and reliable structured questionnaire with a cross-sectional survey design. According to Spearman's test result from total 150 samples, Pemogan Villager knowledge about Usada Taru Pramana is not correlated with the utilization behavior and conservation of herbal medicine $(P$ value $=0,280$ and $r=0,089)$. There were no significant differences between the both variables with respondents' education level, age and gender. The results showed that the factor which influenced the studied variables is very complex. There were "aja wera" belief in Balinese society, which means that the general public is prohibited from learning directly from the Lontar. Pemogan Villager also hampered by the scarcity of land and medicinal plants around them.
\end{abstract}

Keywords: Usada Taru Pramana; knowledge; behavior

\section{INTRODUCTION}

According to the history of pharmaceutical science, many modern medical systems are developed from traditional medicine systems. Traditional treatment systems evolved as local geniuses in various regions.

Treatment procedures developed in Bali are believed to come from Lontar Usada. Lontar is a traditional document that written on palm leaf (Borassus flabelliformis). Usada consists of several lontar including Usada Manak, Usada Cukil Daki, Usada Rare, and Usada Taru Pramana. In contrast to other Lontar Usada, Usada Taru Pramana specializes in the use of medicinal plants. Usada Taru Pramana contains conversations between Mpu Kuturan with around 167 medicinal plants that tell the efficacy of each of them (Jumadiah, 2009).

Nowadays, it's rare to find a person that able to read Lontar Usada. Local genius information in general is given orally. Information transfer orally is not effective, so the information of Usada Taru Pramana have a great possibility to loss in the society. If the information in Usada Taru Pramana is not widely known by public, it is feared that this knowledge of traditional Balinese medicine along with the plants commonly used for long term treatment will disappear.

Pemogan village located in South Denpasar District in Denpasar City in Bali Province. Several

Correspondence author: Ni Putu Udayana Antari

Email: udayana@farmasisaraswati.ac.id
Balian can still be found in the Pemogan village as well as others areas in Bali. Balian is healers in traditional medicine system in Bali. Most of them prescribing herbal medicine. Existence of some Balian in Pemogan shows the high interest of Balinese, especially the Pemogan community, on traditional Balinese medicine. As an area located in the provincial capital, Pemogan Village is equipped with various formal health facilities. Nevertheless, many Pemogan villagers still seek treatment to traditional healers or Balian. There are three types of Balian or Shamans according to the way they get their expertise, namely Balian Kapican, Balian Katakson, and Balian Usada (Nala, 2006).

Research intentions is to solve some of these problems, which are: Does the community have a positive attitude toward the utilization behavior and conservation of herbal medicine? Does the knowledge level of Pemogan Villager about Usada Taru Pramana correlated to the utilization behavior and conservation of herbal medicine? The results of this study are expected to be the basis of further research in the conservation efforts of herbal medicine and traditional medicinal plants.

\section{MATERIAL AND METHODS}

The research done using cross-sectional survey design and purposive sampling system. The research is located in Pemogan village, Denpasar Selatan sub district, Bali Province, at March 2017 till August 2017. 
The research population is all Pemogan villagers. Research sample is 150 person who met the inclusion criteria. The sample was taken using purposive sampling system.

The respondents should meet the following inclusion criteria: Have identity card as Pemogan villagers; Age $\geq 17$ years; Minimum education level is elementary school; Have family members who use herbal medicines.

Willing to fill the questionnaire and able to communicate well.

The number of samples used in this study was calculated using the equations as follows (according to Lemeshow et al., 1997):

$$
n=\frac{\mathrm{Z}_{1}{ }^{2}-\frac{\alpha}{2} \cdot \mathrm{p}(1-\mathrm{p})}{d^{2}}
$$

Explanation:

$\mathrm{n}$ : minimum sample size; $\mathrm{Z}_{1}{ }^{2}-\frac{\alpha}{2}$ : degree of trust 95\% (1.96); p: proportion of population 50\% (0.5); d: level of precision /deviation against population $8 \%(0.08)$.

Minimum sample size is 150 respondents. The respondents were taken from all banjar in Pemogan village (banjar is a community group system under the village).

The research tool is a structured questionnaire consisting of questions related to the knowledge level of Pemogan Villager about Usada Taru Pramana and questions related to attitude toward the utilization behavior and conservation of herbal medicine. Questionnaires are made with closed answers, so the data can be quantified by coding to be analyzed and taken conclusions.

The questionnaire was arranged based on the translation of Lontar from Griya Pendhem Karangasem. The Lontar is stored in Culture Documentation Office of Bali Province. The questionnaires are consulted to the Indonesian grammarian to ensure the questions using proper grammar. So, the questionnaires will not cause the ambiguous meaning when used on the research.

The questionnaire was disseminated to 30 people outside the study subjects for validity and reliability test. The questionnaire for validity and reliability test consists of 100 items of statement, divided into 2 parts, namely 59 points of knowledge statement and 41 behavior statements. The validity test of the questionnaire using the Pearson Correlation Test comparing r-table with $r$ count on each statement. R-value of table for 30 respondents with $5 \%$ trust degree is 0.361 . The reliability test of the questionnaire is carried out with the criteria of testing the Cronbach Alpha count value $>60$.
After the test, data obtained that from 41 points statements on the questionnaire there are 26 valid statements and 15 invalid statements. Whereas from 59 points statements on the questionnaire of knowledge there are 27 valid statements and 32 statements are not valid. So, from a total of 100 items tested, there are 53 valid statements and 47 invalid statements.

The research data was obtained by giving 1 point for the correct answer and the zero (0) point for the wrong answer. The level of public knowledge about Usada Taru Pramana is classified according to table I.

Table I. Classification of Community Knowledge Levels

\begin{tabular}{cc}
\hline Classification & Value (\%) \\
\hline Very good & $81-100$ \\
Good & $61-80$ \\
Sufficient & $41-60$ \\
Less & $21-40$ \\
Very less & $1-20$ \\
\hline
\end{tabular}

Assessment of community behavior is done by giving 1 point if the behavior of respondents leads to the utilization behavior and conservation of herbal medicine. Zero (0) point is given if the respondent's behavior does not lead to the utilization behavior and conservation of herbal remedies. The behavior of the utilization behavior and conservation of herbal medicine of Pemogan Village is classified according to table II.

Table II. Classification of Community Behavior

\begin{tabular}{cc}
\hline Classification & Value (\%) \\
Very positive behavior & $76-100$ \\
Positive behavior & $51-75$ \\
Negative behavior & $26-50$ \\
Very negative behavior & $1-25$ \\
\hline
\end{tabular}

The normality of community knowledge and behavior's data were tested using Kolmogorov Smirnoff Test, followed by bivariate analysis. The data of the correlation between Pemogan village's knowledge about Usada Taru Pramana with the utilization behavior and conservation of herbal medicine was tested using Spearman correlation coefficient.

\section{RESULT AND DISCUSSION \\ Characteristics of Respondents Research}

Most respondents were female (63.3\%). Age of respondents was divided into two categories, namely $\geq 30$ years old and $<30$ years old. Most respondents were over 30 years old (74\%). The 
education level of the respondents was divided into two categories namely respondents with low education level and respondents with high education level. Most respondents have low education (77.33\%). More data were presented in table III.

Table III. Characteristics of respondent

\begin{tabular}{lcc}
\hline Variables & Amount & Percentage (\%) \\
\hline Gender & & \\
Female & 95 & 63,33 \\
Male & 55 & 36,67 \\
Age & & \\
$\leq 30$ years & 39 & 26 \\
> 30 years & 111 & 74 \\
Level of education & & \\
High (post graduate) & 34 & 22,67 \\
Low (under graduate) & 116 & 77,33 \\
\hline
\end{tabular}

The knowledge of Pemogan Village community about Usada Taru Pramana as well as the community behavior related to the utilization behavior and conservation of herbal remedies were presented in table IV. In table $\mathrm{V}$ it shows the number of respondents in each category of knowledge and behavior. Pemogan community knowledge about Usada Taru Pramana belongs to good category, with a value of $66.3 \%$. This result shows that Pemogan people still concern about the contents of Usada Taru Pramana. Nevertheless, there were some questions that unable to be answered by some respondents. If it is sorted, the three questions that have the most wrong answers are as follows: Only 59 persons from 150 respondents have answered correctly that according to Usada Taru Pramana, Wani (Mangifera caesia jack) can be used for curek (otitis media) treatment; Only 77 persons from 150 respondents have answered that they had heard about Usada Taru Pramana; Only 78 persons from 150 respondents have answered correctly that Pangi (Pangium edule) can be used to compress koreng (pioderma).

Table IV Classification of Community knowledge and community behavior in Pemogan

\begin{tabular}{lcc}
\hline Variables & Value (\%) & Classifications \\
\hline $\begin{array}{l}\text { Knowledge of Usada } \\
\text { Taru Pramana }\end{array}$ & 66.43 & good \\
$\begin{array}{l}\text { Behavior of utilization } \\
\text { and conservation of } \\
\text { herbal medicine }\end{array}$ & 64.13 & positive \\
\hline
\end{tabular}

The result of research indicates that according to the Classification of Community
Behavior (Table II), the behavior of Pemogan villager to utilize and conserve the herbal medicine classified as positive with value $64,13 \%$. It was shows that Pemogan community tends to support the utilization and conservation of herbal medicine. Most respondents (141 people) behave positively toward the utilization and conservation of herbal remedies. Only 9 out of 150 respondents whose behavior does not support the utilization and conservation of herbal remedies.

Table V. The number of respondents by category of knowledge and behavior level

\begin{tabular}{clcc}
\hline Variables & Classification & Value & $\begin{array}{c}\text { Percentage } \\
\text { (\%) }\end{array}$ \\
\hline \multirow{5}{*}{ Knowledge } & Very good & 46 & 30,67 \\
& Good & 46 & 30,67 \\
& Sufficient & 40 & 26,67 \\
& Less & 17 & 11,33 \\
& Very less & 1 & 0,66 \\
& Total & $\mathbf{1 5 0}$ & $\mathbf{1 0 0}$ \\
& Very positive & 103 & 68,67 \\
Behavior & Positive & 38 & 25,33 \\
& Negative & 0 & 0 \\
& Very negative & 9 & 6 \\
& Total & $\mathbf{1 5 0}$ & $\mathbf{1 0 0}$ \\
\hline
\end{tabular}

The result of bivariate analysis that has been done was presented in table 6 . According to Spearman test result there was no significant correlation between the level of public knowledge about Usada Taru Pramana and behavior of society about utilization and conservation of herbal medicine. The high or low knowledge of Pemogan Society about Usada Taru Pramana not related to community behavior in the utilization and conservation of herbal medicine. Similar results were also obtained for other factors such as education, sex, and age.

The results showed that the factor that influenced the studied variables were very complex. In other hand, the variables that observed in this study only knowledge, age, education, gender, and education level. There were many factors that influence the occurrence of behavior, according to WHO theory, which are: Results of person thoughts and feelings. They were influenced by knowledge, beliefs, and attitudes; Reference from a trusted person; Available resources; Culture, customs, values, and traditions that exist in the community.

Suryadharma (2007) stated that many people use traditional medicine system from Taru Pramana. However, they simply do it based on the ancestor's customs without questioning the source or reason of any action taken. 
Table VI. Results of correlation analysis

\begin{tabular}{|c|c|c|c|}
\hline Correlation analysis & $\mathbf{r}$ & P value & Information \\
\hline $\begin{array}{l}\text { The correlation between knowledge of Usada Taru Pramana and } \\
\text { utilization behavior and conservation of herbal medicine }\end{array}$ & 0,089 & & \\
\hline $\begin{array}{l}\text { he correlation between level of education and community } \\
\text { nowledge about Usada Taru Pramana }\end{array}$ & $-0,070$ & 0,397 & $\begin{array}{l}\text { No significant } \\
\text { correlation }\end{array}$ \\
\hline $\begin{array}{l}\text { f education and community } \\
\text { on of herbal medicine }\end{array}$ & $-0,074$ & 0,365 & \\
\hline $\begin{array}{l}\text { The correlation between gender and community knowledge about } \\
\text { Usada Taru Pramana }\end{array}$ & -0.020 & 0,807 & $\begin{array}{r}\text { No s } \\
\text { cor }\end{array}$ \\
\hline elation between sex and community behavior of utilization & 0,092 & 0,261 & $\begin{aligned} \text { No s } \\
\text { cor }\end{aligned}$ \\
\hline he correlation between age and community knowledge about the & $-0,037$ & 0,650 & \\
\hline $\begin{array}{l}\text { ne correlation between age and community behavior of } \\
\text { ilization and preservation of herbal medicine }\end{array}$ & 0,079 & 0,334 & $\begin{array}{l}\text { No significant } \\
\text { correlation }\end{array}$ \\
\hline
\end{tabular}

The Balinese were accustomed to 'nak mule keto' answer, which mean: "it's been always like that since ancient times" and there was no reason for any action taken. The statement was reinforced by the results of research that shows the knowledge of respondents about Usada Taru Pramana was quite good, but among 150 respondents only 77 persons ever heard about Usada Taru Pramana.

The phenomenon is in accordance with the belief of 'aja wera' widely known by the people of Bali. In such belief, the general public was prohibited from learning directly from the Lontar. Only certain people can read Lontar. This make the knowledge of Usada derived without mentioning the source. The community was taught how to use herbs from generation to generation, but the source information was not mentioned.

The level of education (post graduate and under graduate) was not related to public knowledge about Usada Taru Pramana.

There was no correlation between the utilization behavior and conservation of herbal medicine and education level in Pemogan Community. Information of Usada Taru Pramana in general was not given in formal education. Information of traditional treatment systems was given orally in one family line in general. Knowledge level of Pemogan Villager about Usada Taru Pramana and utilization behavior and conservation of herbal medicine were not predicted by gender of respondent.

There were two groups of age: $\geq 30$ years and $<30$ years. Based on that age groupings, researchers can't predict the Knowledge level of Pemogan Villager about Usada Taru Pramana and utilization behavior and conservation of herbal medicine. Statement from Suryadharma (2007):
There were significant differences between the group of people aged $>60$ years with the group of respondents aged 15-25 years. Usada as a science of traditional medicine was left behind the time and the interest of the younger generation to learn Usada decreases. The generations who really understand traditional medicine system especially Usada Taru Pramana is getting older. This causing the age grouping in this study can't show the correlation between the age and the level of knowledge about Usada Taru Pramana.

The complexity of urban life was also expected to influence the utilization behavior and conservation of herbal medicine in Pemogan Community. Pemogan Villager hampered by the scarcity of land and medicinal plants around them, especially existing plants in Lontar Usada Taru Pramana. So, it's hard to show the real utilization behavior and conservation of herbal medicine in Pemogan Community

\section{CONCLUSION}

Conclusions that can be drawn based on the results of the research are as follows: The level of knowledge of the people of Pemogan Village about Usada Taru Pramana is categorized as good with an average percentage of $66.43 \%$; Pemogan Village community has a positive attitude toward the utilization behavior and conservation of herbal medicine with an average percentage of $64,13 \%$; Pemogan community knowledge about Usada Taru Pramana is not correlated with the behavior of the utilization and preservation of herbal medicine.

\section{ACKNOWLEDGEMENT}

This research was supported by Direktorat Riset dan Pengabdian Masyarakat Direktorat 
Jenderal Penggunaan Riset dan Pengembangan, Kementrian Riset, Teknologi, dan Pendidikan Tinggi. The author thanks the Chief of Desa Pemogan, Chief of each Banjar in Pemogan, all Pemogan villager and Taru Pramana team for their kindness to help in the research, I Gede Nyoman Jaya Nuraga for the help in statistical analysis and Ni Made Dharma Shantini Suena for the help on arranging this journal.

\section{REFERENCES}

Jumadiah, Sri, 2009, Usada Taru Pramana, Yayasan Dharma Pura, Denpasar.
Lemenhow, S. Hosmer Jr. D.W. Klar, J. and Lwanga, S.K., 1997, Besar Sampel dalam Penelitian Kesehatan, translated by Dibyo Pramono, Gadjah Mada University Press, pp 54-55, Yogyakarta.

Nala, N., 2006, Aksara Bali dalam Usada, Paramita, Surabaya

Suryadharma, 2007, Perbanyakan Satuan Paket Naskah Usada Taru Pramana Dalam Alternatif Media Multi Bahasa: Prosiding Seminar Konservasi Tumbuhan Usada Bali dan Peranannya dalam Mendukung Ekowisata, pp 391-395. 